
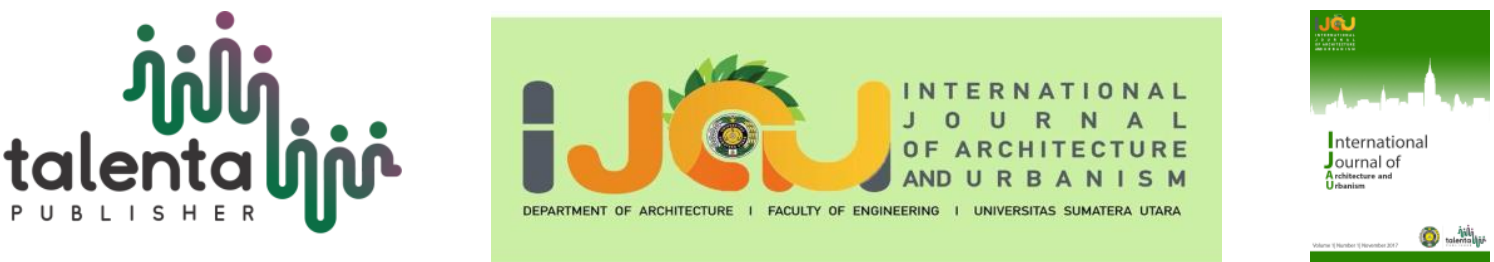

\title{
Ecological Aspects of Urban Structure of The Balige District Kabupaten Toba, Indonesia
}

\author{
Rafika Hilmi Nasution ${ }^{*^{*}}$ \\ ${ }^{I}$ Independent Researcher, Deli Serdang District, North Sumatera Regency, Indonesia
}

\begin{abstract}
Balige is the capital of Toba Samosir Regency. Balige District continues to develop dynamically, marked by the development and changes of the physical city structure Balige. It is about the real implications of a city's physical growth and development that move dynamically, which can be seen from urban, suburban, and rural land-use patterns. The aim is to determine the ecological aspects of urban structures in the Balige District. The method used in selection is done through secondary data that does not directly provide data to researchers or analyzed documents and concluded. Initially, Balige City was centered on the pier up to Sisingamangaraja's field, evidenced by water transportation still used today. However, the result of the study showed changes in the pattern of land use due to economic growth and social transformation
\end{abstract}

Keyword: Balige District, ecological, land use

Received 25 September 2021 |Revised 27 October 2021 | Accepted 30 October 2021

\section{Introduction}

Balige is one of the busiest cities in the Toba Samosir Regency area because Balige is the capital of Toba Samosir Regency and is a Sumatran cross route. Since ancient times Balige has often been the center of trade because of its strategic location. The government center of Balige City is centered on the Balige pier to the Sisingamangaraja field. In addition to being a traditional trade exchange, Balige was also a political center in its era, precisely during the ancient Batak kingdom, more specifically in the Bakkara Kingdom Dynasty [1].

The area of Balige District is $91.05 \mathrm{~km}^{2}$, with a population of 44,635 people. Balige Subdistrict is bordered by Lake Toba on the north side, is bordered by Laguboti Subdistrict on the east side, bordered by North Tapanuli Regency on the south, bound by Tampahan District on the west side [2].

\footnotetext{
*Corresponding author at:Jalan Juang 45 No. 15, 20371, Deli Serdang, North Sumatera, Indonesia

E-mail address: rafikahilmi06@gmail.com
}

Copyright $@ 2021$ Published by Talenta Publisher, 
In connection with the issuance of the Toba Samosir Regency RPJM, the development of the Balige District is focused as a primary service center unit for the function of the Lake Toba area, which consists of protection and tourism of Lake Toba. It is supported by the livestock, plantation, horticulture, and fishery sub-sectors. In addition, the Balige District is also used as the central transportation hub connecting to/from the National Activity Center and Regional Activity Center [3].

Land use is defined as a human intervention to fulfill their spiritual and material needs. Meanwhile, according to Suparmoko, land use also depends on where the site is located, especially in settlements, industrial locations, and recreational areas. The elements of land use are designed by considering land-use policies, which aim to adjust the design and procedures in the designation of land in a particular area [4].

The indications for the 2011-2031 Toba Samosir Regency Spatial Plan program are that the spatial structure and spatial patterns of Toba Samosir Regency are grouped into three groups. First, (a) the urban system in Toba Samosir Regency, where Balige Subdistrict is designated as the center of urban area activities. (b) Directions on spatial structure related to the creative sector, where the Balige City detailed layout plan is drawn up, the preparation of strategic building and environmental planning plans, improvement and development of government facilities and infrastructure, progress and development of waste and wastewater facilities and infrastructure, city roads and environmental roads, urban drainage, provision of urban drinking water, transportation facilities and infrastructure, green open space, tourism, medium and small industries, housing and settlements, revitalization and structuring of Lake Toba suburbs and the construction of WWTPs.

Cities are considered hybrid ecosystems because they show unique characteristics, patterns and behaviors, originating from complex interactions between humans and their environment [5]. With the city's current development, it is essential to ask, "how does the ecological aspect affect the urban structure of the Balige District?". This study aims to show how the ecological aspect affects the spatial structure in Balige District. 


\section{Literature Review}

Government regulatory policies regarding land use in an area also affect land use. The increasingly rapid growth in urban areas can be seen from land use, such as changes in agricultural land use into trade and service areas. Several factors cause land conversions, such as population growth, employment, infrastructure and facilities, and government regulations. Four factors cause changes in land use: high levels of urbanization, slow development in rural areas, and an increase in the number of middle to upper-income people in urban areas cause increased demand for housing/settlements [6].

Puspitasari, et al. in [7] told that the development of a city can be influenced by several factors, namely: (a) physical factors (location and geographical conditions) and non-physical factors (population development and urban activities); (b) accessibility, public services, land characteristics, landowners, the existence of land use arrangements, developer initiatives.

The variables that affect the improvement of a city's structure are topographical conditions because it affects the needs and circumstances. Urban as the center of circulation, for example, is located in the center of the cross-provincial route or close to the port. Seaside cities, generally seaside cities, are crescent-shaped, with the focal point of the circle being the port. In addition to topography, geography/landforms are also affected because landforms can be a barrier to space development. However, human efforts to change an environment are significant, such as digging a slope and plowing the land. People living in lowlands will develop significantly compared to people living in hilly areas [8].

Ecology as a research method studies the relationship between the artificial environment and the surrounding natural environment. The village as a place to live, human life and livelihood, is an ecological object of cultural products that continue to develop, including nature, humans, society, the built environment, and infrastructure networks [9]. The relationship between humans and nature greatly influences development. Should combine development plans with the use of natural resources to avoid misuse of natural resources. The ecological planning model uses natural cycles or laws, and energy intensity to a minimum [10].

From the description above, it can conclude that the ecological aspect consists of topography and landforms. Topography and landforms consist of a road network system, the arrangement of building masses, land use, the development of a city, and the shape of a town. These components will form the urban structure. 


\section{Methodology}

The study approach used in this research is to use quantitative methods with secondary data collection techniques. Secondary data is data obtained indirectly by conducting field surveys. In data collection, secondary information is obtained from journals, theses, government regulations, or sites related to the ecological aspects of an urban area. The information obtained is in land use in Balige District, ecological aspects of Balige District, and policies related to land use development in Balige District. The information that has been obtained is then presented in the form of tables or images that are still illustrative. In addition, it is also equipped with photographs that clarify the location of this research.

\section{$4 \quad$ Results and Analysis}

This research is located in Balige District. Balige District is situated at an altitude of 905-1,200 meters above sea level. This sub-district consists of 29 villages and six sub-districts. There are nine villages directly adjacent to Lake Toba and 26 villages not directly neighboring Lake Toba. The following is an administrative map of the research location (Figure 1) [2] [11].

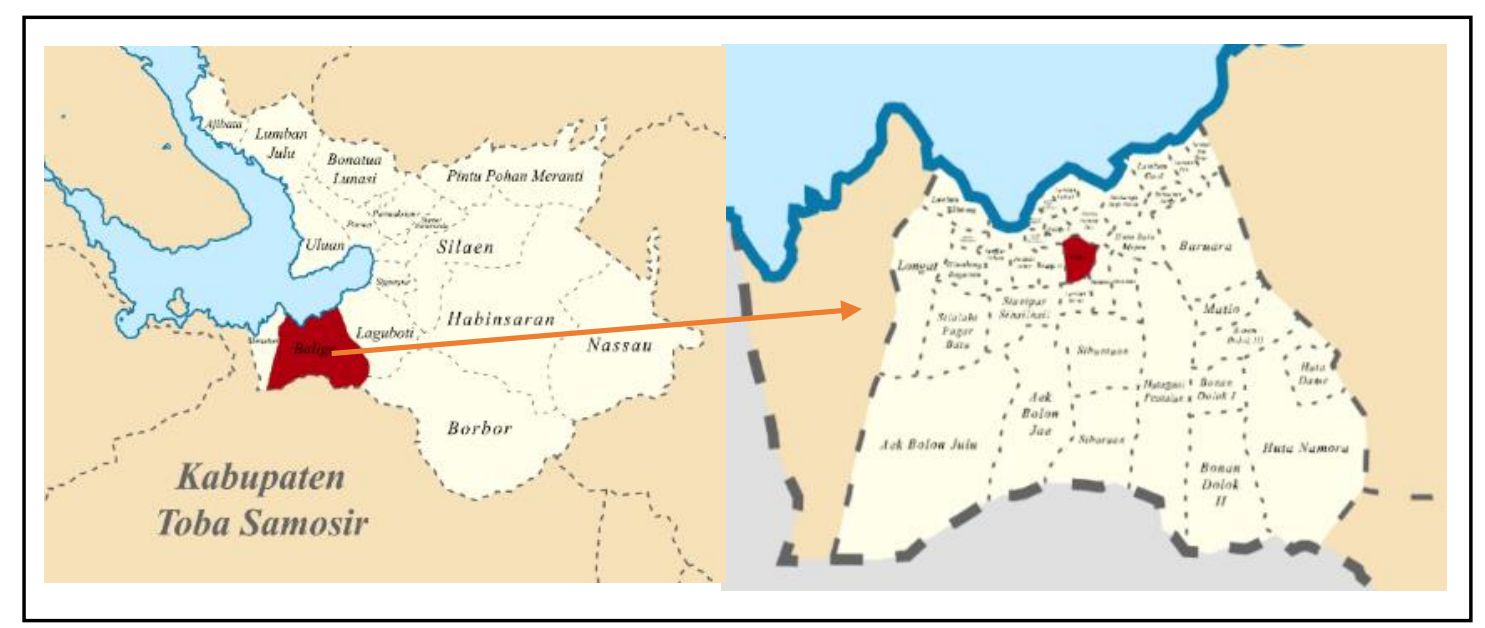

Figure 1 Project Location

Land use is a human activity directly related to the location and condition of the land. Land use is a continuous process in using a site that aims to develop optimally and efficiently. For land use in Balige District, it can be seen in the Table 1. 
Table 1 Land use of Balige District

\begin{tabular}{ll}
\hline No. & \multicolumn{1}{c}{ Land use } \\
\hline 1. & Settlement \\
2. & Tourism \\
3. & Trading \\
4. & Industry \\
5. & Educational Facilities \\
6. & Medical Facility \\
7. & Agriculture \\
8. & Dry Land \\
9. & Ricefield \\
\hline
\end{tabular}

\section{Settlement Land Use Analysis}

Initially, the land use pattern in Balige District was dominated by rice fields, dry forest land, and settlements. However, over time there has been a shift in land use in Balige District. The population growth significantly every year in Balige District increased land use. Settlements are the leading cause of land-use change in the Balige District [12] [13].

The growth of residential areas comes from dry land, shrubs, and rice fields. The conversion of land into settlements signifies that the settlements are scattered randomly and irregularly throughout Balige District. New settlements generally occur around areas of pre-existing settlement land in clustered and irregularly distributed patterns (Figure 2).

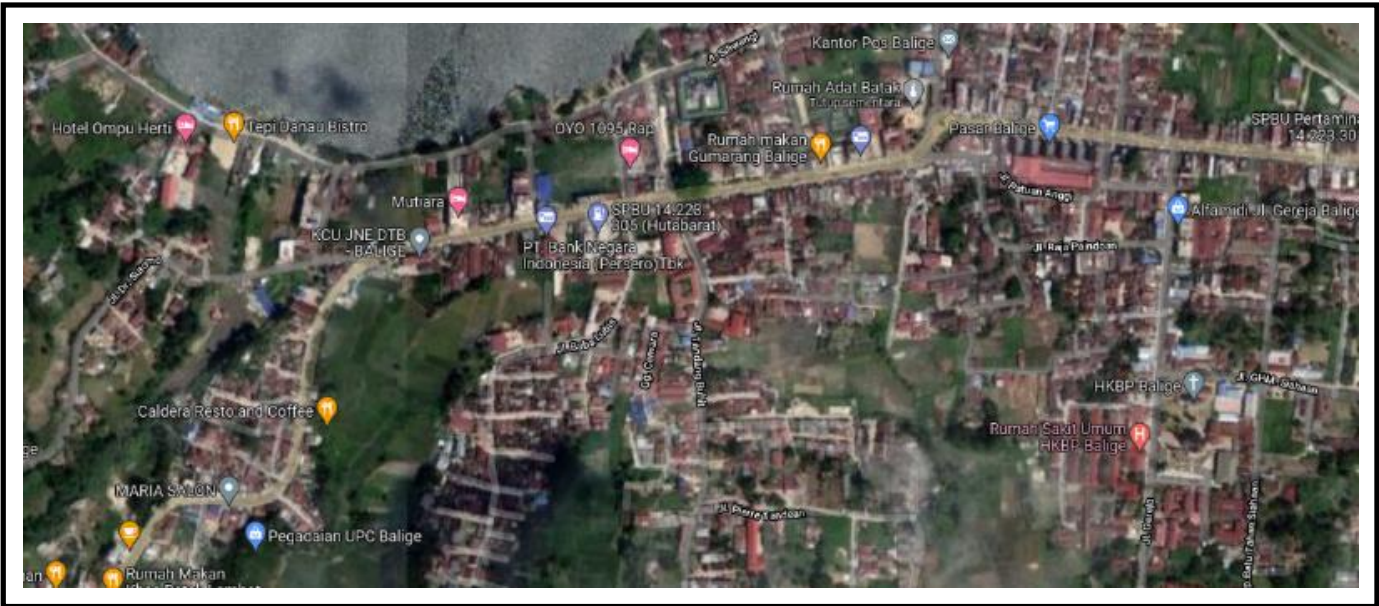

Figure 2 Settlements in Balige City which are scattered irregulary

\section{Tourism Land Use Analysis}

Balige District is directly adjacent to Lake Toba. This ecological factor has made the government direct Balige City to tourism according to Presidential Decree 81 of 2014 and the spatial plans of Toba Samosir Regency in 2017-2037 [6] [14]. Balige District is also growing, of course, affects the growth of development related to land use. Changes in land use in the Balige sub-district about the tourism component are scattered in urban and rural areas. There has been 
an increase in land use for tourism component land use in the Balige City area. These components include accommodation facilities (hotels), eating and drinking facilities (cafes, restaurants), transportation services, and travel agencies (Figure 3).

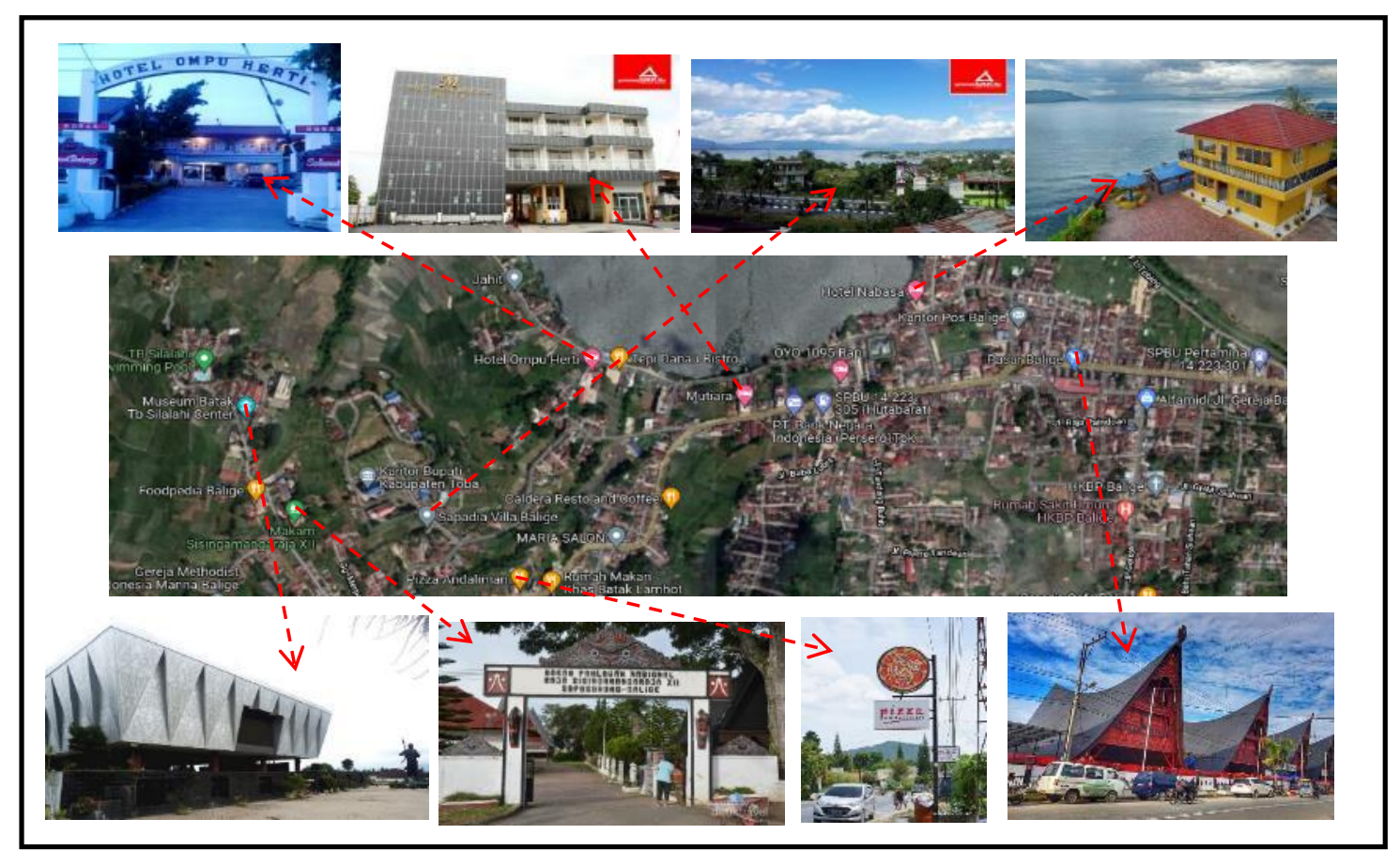

Figure 3 Several components of tourism in Balige District

\section{Trade Land Use Analysis}

The number of trade facilities in an area can describe the level of economic development of a region. Because it is a cross-course of Sumatra, and the capital of Toba Samosir Regency, the city's strategic location causes changes in land use to support urban activities [2]. Trading facilities in Balige District have proliferated. Balige sub-district has four market units, one of which is Onan Balerong which was established in 1938. There are 460 units of shops/grocery stalls, as well as 94 units of restaurants. Commercial land uses are generally scattered in the center of Balige City (Figure 4).

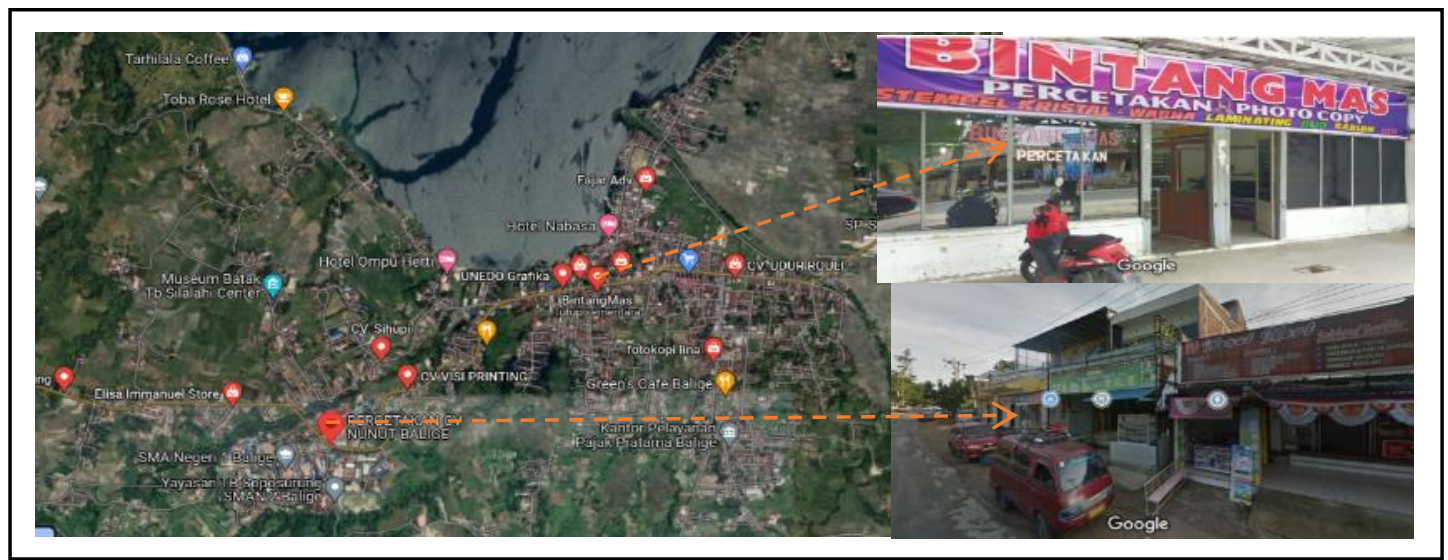

Figure 4 Land use for trade and services 


\section{Industrial Land Use Analysis}

As the capital of Toba Samosir, industrial activities in Balige District do not yet have a large industry. Industries that develop in Balige are generally medium, small, and micro [2]. Mediumsized industries are usually companies, while small or micro industries are still not legal entities and are managed by the community. Nevertheless, industrial activities continue to develop in Balige, which causes the land use to be said to be less organized due to the conversion of land into industrial land. Generally, this land conversion is dominated by small or micro industries that develop in Balige District. Small or micro industries are typically involved (Figure 5).

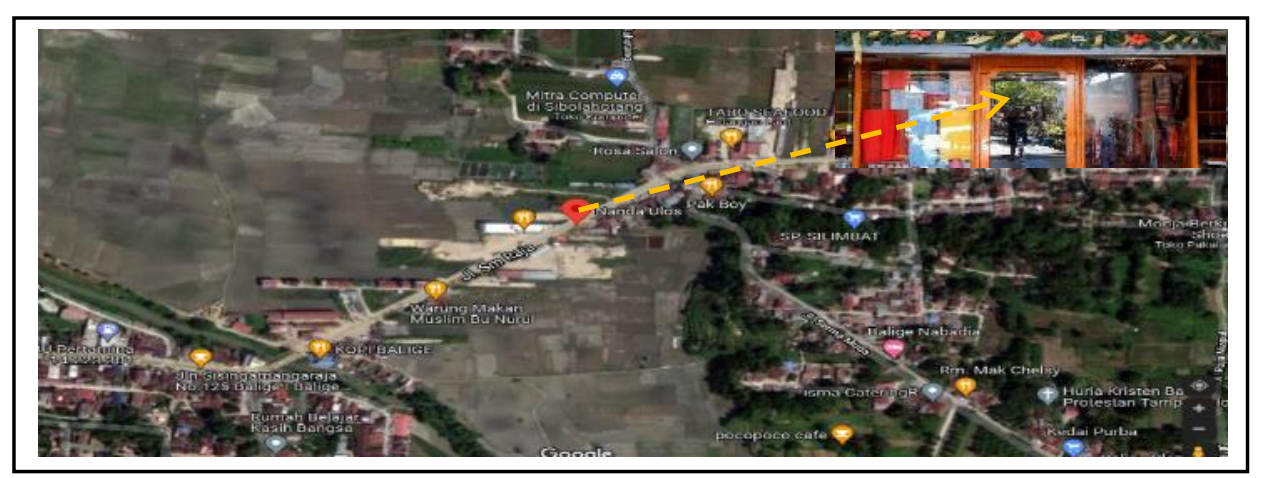

Figure 5 Example of industrial land use in Balige District

\section{Agricultural Land Use Analysis}

The geographical condition of Balige District is in a highland area surrounded by hills/mountains. Balige's topography is hilly, undulating, and flat. Therefore, geographically, Balige District is spoken of as an agricultural area. There are rice fields scattered throughout Balige District (Figure 6).

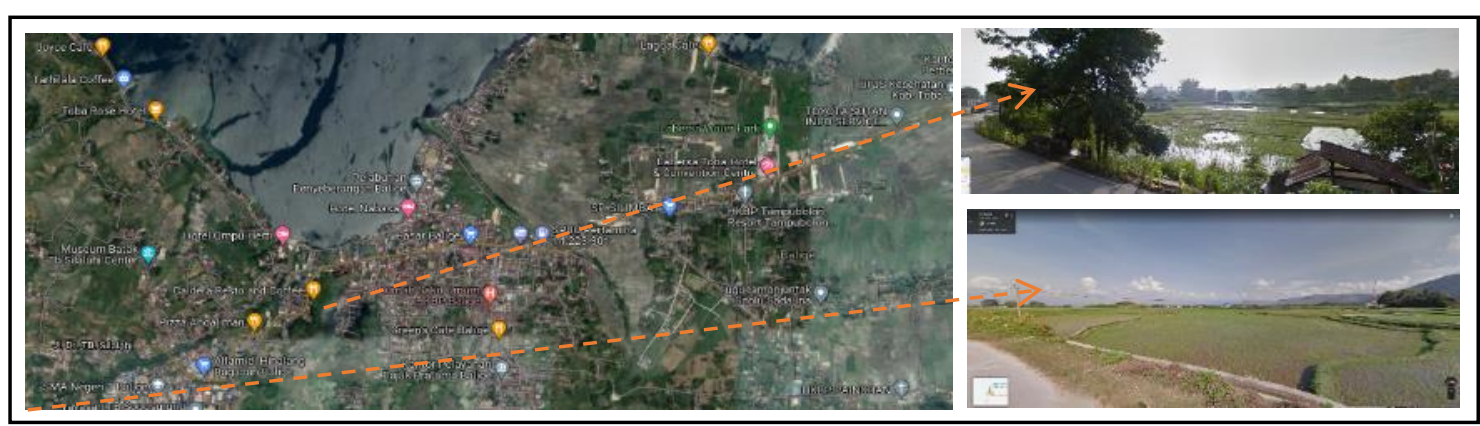

Figure 6 Example of agricultural land use in Balige District

\section{Land Use Analysis for Sea Transportation}

Balige District is directly adjacent to one side (edge) of Lake Toba on the southeast side. In ancient times the shores of Lake Toba were used by residents of Balige as a transportation route and to catch fish. Along with the times, the exchange of agricultural products between regions 
in the Lake Toba area causes water transportation to increase. The small canoe changed to a giant canoe which then changed again to a layer boat and changed again to a motor boat [15].

Lake Toba is the entry/exit route to Samosir Island or the Tele Line, the only land route connecting Samosir Island with mainland Sumatra. The Tele line has very tough terrain because it is a steep hilly area, so people prefer to use motor boats to Samosir Island. On this basis, a pier was built at Balige Harbor (Figure 7).

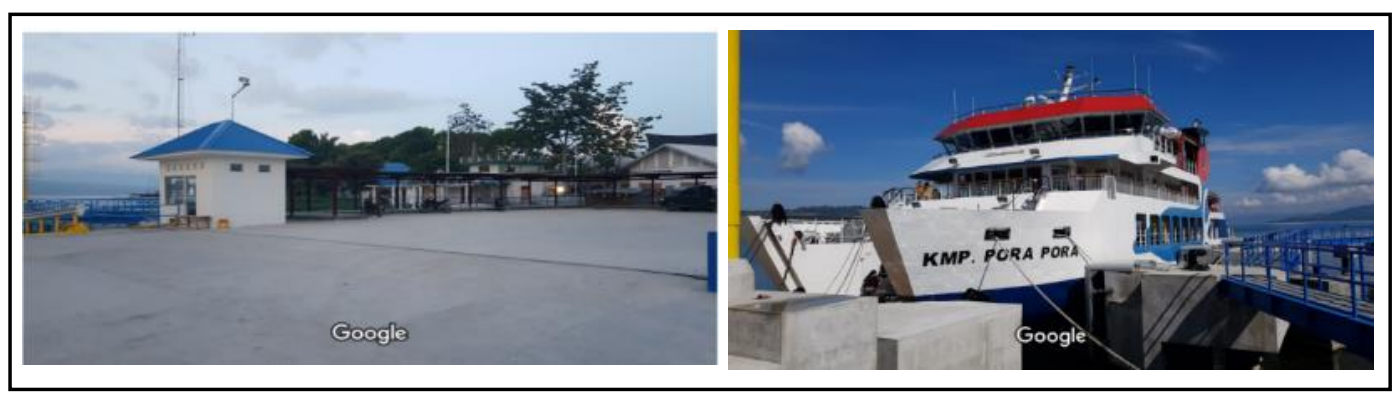

Figure 7 Balige ferry port

\section{Road Network Analysis}

Balige District is located on the Sumatran cross route, which is right across the center of Balige City. Thus, the arterial road corridor in the Balige District has a vital function and role, especially in terms of the mobility of people and goods between North Sumatra to/from West Sumatra. The circulation of vehicles on the streets of Balige City causes congestion during peak hours, namely when entering/returning from work or school. Through the 2016-2035 spatial plans, the Toba Samosir Regency Government plans to build the Balige ring road to reduce the traffic load in the middle of the city, namely on Jalan Sisingamangaraja - Patuan Nagari. The ring road named Jalan Balige Bypass connects Jalan Sisingamangaraja to the north and west as an alternative route to pass through the center of Balige City. In addition to arterial roads, the Balige road network system consists of collector roads and local roads (Figure 8).

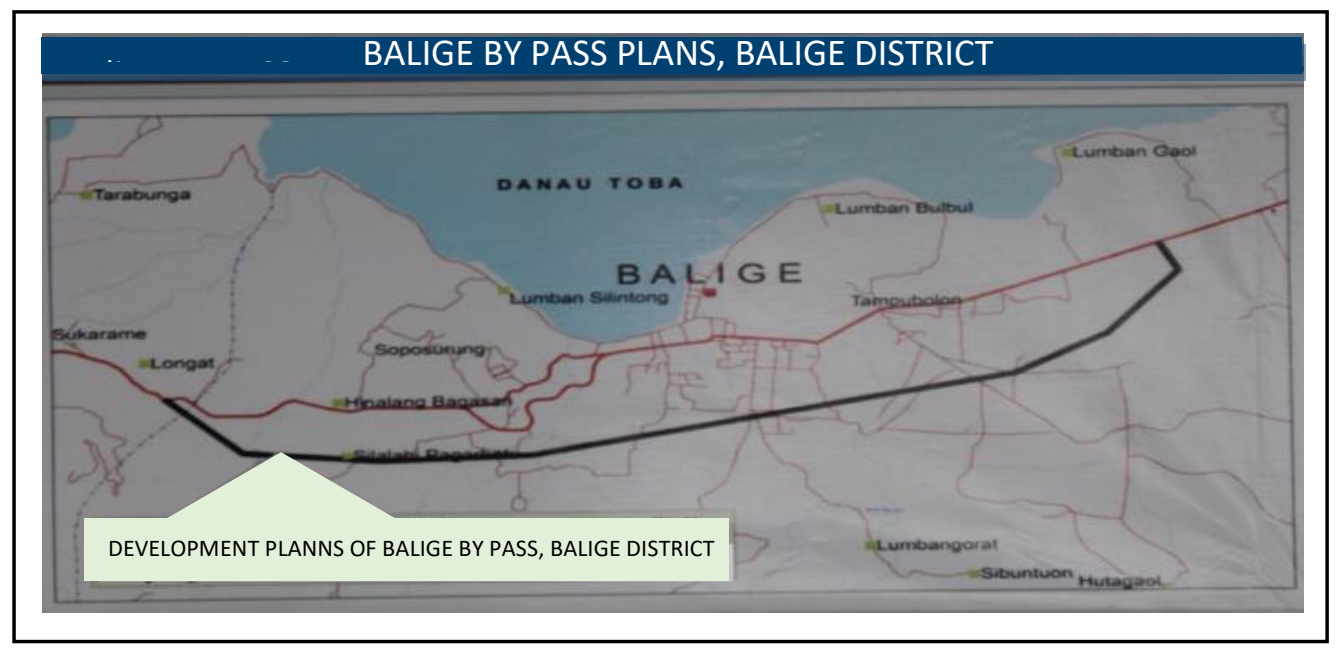

Figure 8 Balige By Pass planning map 


\section{Conclusion}

The ecology of the Balige sub-district seems to have changed in line with the morphology of the Balige sub-district. At first, the form of the City of Balige District centered on Lake Toba, where the Balige pier was a transportation center and traditional trade market. Along with economic and social developments that cause changes in the structure of the City of Balige.

Based on the study results, it can conclude that the morphology of the Balige District, which was initially centered on Lake Toba, has developed, which can be seen from the current land use of the Balige District. Along with advances in technology, human resources, and the economy of a city, as well as government intervention in preparing urban spatial plans, Balige District is increasingly incorporating ecological elements into its urban planning and development.

\section{Acknowledgment}

This research contributes to the government of Toba Samosir Regency in formulating policies related to Detailed Spatial Planning in Balige District regarding the influence of ecological aspects on land use patterns in Balige District. The author would like to thank the Master of Architectural Engineering, Universitas Sumatera Utara for all the guidance in completing this research.

\section{REFERENCES}

[1] Batak, Lirik Lagu, "Sejarah Singkat Kota Balige, Pusat Pemerintah dan Tempat Berkumpulnya Raja Batak," April 3, 2019. [Online]. Available: https://liriklagubatak.com/sejarah-singkat-kota-balige.html. [Accessed: Oct. 7, 2021].

[2] Badan Pusat Statistik Kabupaten Toba Samosir, Kecamatan Balige Dalam Angka 2021. Balige: Badan Pusat Statistik Kabupaten Toba, 2021. [Online]. Available: https://tobasamosirkab.bps.go.id. [Accessed: Oct. 7, 2021].

[3] Dinas Tata Ruang dan Permukiman Kabupaten Toba Samosir, Rencana Program Investasi Jangka Menengah Kabupaten Toba Samosir. Samosir: 2017.

[4] B. Setiawan, "Kajian Perubahan Penggunaan Lahan Dan Struktur Ruang Kota Bima," in Jurnal Pembangunan Wilayah dan Kota, vol. 12 (2), pp.154-168, Juni 2016.

[5] E. Lindia Mayona, "Pergeseran Makna Kota Berdasarkan Perspektif Lingkungan," Jurnal Online Institut Teknologi Nasional, vol. 01, pp. 35-43, May 2021. [Online].

[6] AR. Sianipar, Kajian Perubahan Penggunaan Lahan Ditinjau dari Faktor Kebijakan Pengembangan Pariwisata (Studi Kasus: Koridor Jalan Arteri Kecamatan Balige Pada Tahun 2009-2019). M.T. [Thesis]. Medan, Univ. Sumatera Utara, Indonesia, 2021. [Online]. Available: Repositori.usu.ac.id

[7] N. Puspitasari, and W. Pradoto, "Faktor Yang Mempengaruhi Perubahan Lahan Dan Pola Perkembangan Permukiman Kawasan Pinggiran (Studi Kasus: Daerah Gedawang, Kota Semarang)," Teknik PWK (Perencanaan Wilayah Kota), vol. 2, no. 3, pp. 638-648, Aug. 2013.

[8] MC Branch, and Wibisono, B.H., "Perencanaan Kota Komprehensif: pengantar dan penjelasan" Gadjah Mada University Press, 1995.

[9] E. Wulandari, and F. Aulia, "Pengaruh Morfologi Kota Terhadap Ekologi Perkampungan Tradisional Di Kota Banda Aceh, Indonesia," Jurnal Arsitektur Zonasi, vol. 1, no. 1, June 2018. 
[10] RA. Lestari, and LN. Napitupulu, B. O. Y. M., "Kajian Aspek Ekologi dalam Membentuk Perkampungan di Kawasan Pangururan," in Talenta Conference Series: Energy and Engineering (EE), vol. 2, no. 1, June 2019.

[11] F. Hutapea, "Morfologi Kota Balige Kabupaten Toba Samosir," MS. Thesis, Univ. Negeri Medan, Medan, Indonesia, 2016.

[12] E. Marpaung, "Analisis Perubahan Penggunaan Lahan Dengan Menggunakan SIG Tahun 2009 dan 2016 di Kecamatan Balige Kabupaten Toba Samosir," M.S. Thesis, Univ. Negeri Medan, Medan, Indonesia, 2016.

[13] M. Sitohang, "Kajian Pola Perilaku Penggunaan Tanah Pada Kawasan Pinggiran Danau Toba di Inti Kota Balige," in Seminar Nasional "Kearifan Lokal dalam Keberagaman untuk Pembangunan Indonesia”, 25 January 2018, Universitas Sumatera Utara: Medan [Online]. Available: http://digilab.mercubuana.ac.id. [Accessed: 9 Oct. 2021].

[14] AS. Zendrato, and B.OY. Marpaung, "Kajian Pemanfaatan Tepi Danau Toba Sebagai Ruang Terbuka (Waterfront) Pada Inti Kota Balige," in ," in Seminar Nasional "Kearifan Lokal dalam Keberagaman untuk Pembangunan Indonesia”, 25 January 2018, Universitas Sumatera Utara: Medan [Online]. Available: http://digilab.mercubuana.ac.id. [Accessed: 9 Oct. 2021].

[15] S. Lumban Gaol, Evaluasi Pola Pergerakan Orang dan Barang Dengan Moda Transportasi Air: Studi Kasus: dari dan ke Kota Balige. M.T. [Thesis]. Medan, Univ. Sumatera Utara, Indonesia, 2021. [Online]. Available: Repositori.usu.ac.id 